\title{
Consequences of the Prolonged Waiting Time for Patients Candidates for Heart Surgery
}

\author{
Nagib Haddad, Olímpio J. N. V. Bittar, Ana A. M. Pereira, Maria Barbosa da Silva, Vivian L. Amato, \\ Pedro S. Farsky, Auristela I. O. Ramos, Marcelo Sampaio, Tarcísio L. V. Almeida, Dikran Armaganijan, \\ José Eduardo M. R. Sousa \\ São Paulo, SP - Brazil
}

\begin{abstract}
Objective - To assess mortality and the psychological repercussions of the prolonged waiting time for candidates for heart surgery.

Methods - From July 1999 to May 2000, using a standardized questionnaire, we carried out standardized interviews and semi-structured psychological interviews with 484 patients with coronary heart disease, 121 patients with valvular heart diseases, and 100 patients with congenital heart diseases.
\end{abstract}

Results - The coefficients of mortality (deaths per 100 patients/year) were as follows: patients with coronary heart disease, 5.6; patients with valvular heart diseases, 12.8; and patients with congenital heart diseases, $3.1(p<0.0001)$. The survival curve was lower in patients with valvular heart diseases than in patients with coronary heart disease and congenital heart diseases $(p<0.001)$. The accumulated probability of not undergoing surgery was higher in patients with valvular heart diseases than in the other patients $(p<0.001)$, and, among the patients with valvular heart diseases, this probability was higher in females than in males $(p<0.01)$. Several patients experienced intense anxiety and attributed their adaptive problems in the scope oflove, professional, and social lives, to not undergoing surgery.

Conclusion - Mortality was high, and even higher among the patients with valvular heart diseases, with negative psychological and social repercussions.

Keywords: waiting lists for heart surgery, myocardial revascularization surgery, valvular heart surgery

Instituto Dante Pazzanese de Cardiologia - Secretaria de Saúde do Estado de São Paulo

Mailing address: Nagib Haddad - Instituto Dante Pazzanese de Cardiologia - Av. Dr. Dante Pazzanese, 500 - $5^{\circ}$ andar - 04012-909 - São Paulo, SP, Brazil - E-mail: diretoriaidpc@uol.com.br

English version by Stela Maris C. e Gandour
The great number of patient candidates for heart surgery usually exceeds the availability of hospital resources, even in economically developed countries, resulting in the organization of waiting lists for medium- and long-term medical assistance of these patients ${ }^{1-9}$.

The long waiting time may cause several problems for the patients, their families, and society. In regard to the patients, their condition may worsen, and death may even occur, resulting in psychological problems and repercussions for their families. For society, when the patient is unable to work, the consequences are a decrease in productivity and an increase in the cost of health insurance, and, for those who die early, the social cost of the lost future years of productivity is the consequence. Therefore, it is important to know what is happening to patients during the waiting time for elective surgery.

The objective of this study was to assess, by means of interviews, the mortality and psychological status of patients on waiting lists for myocardial revascularization surgery, and for surgeries of valvular heart diseases and congenital heart diseases in a public hospital specializing in cardiology.

\section{Methods}

The population studied consisted of patient candidates for heart surgery, who were on 3 waiting lists, one for myocardial revascularization, one for valvular heart disease surgeries, and one for congenital heart disease surgeries, until December 31, 1998, at the Instituto Dante Pazzanese de Cardiologia of the Secretaria de Saúde do Estado de São Paulo. Several patients were not placed on waiting lists because the emergency character of the intervention in more severe cases did not justify a more prolonged wait.

We completed a questionnaire containing data copied from the patients' medical records, such as identification, address, telephone number, diagnosis, functional class, surgical indication and respective date, whether it was or 
was not an emergency, and data to be collected during the interview, such as the presence of complications and death, assessment of the current functional class, hospital where surgery was performed, and the waiting time.

The waiting time was defined as the period between the date of placement on the list and the date of surgery, or of death or interview, when none of the first 2 events had occurred.

The team performing the interviews comprised 3 trained and standardized trainees in social services supervised by a social services scientific researcher, 6 trainees in psychology supervised by a scientific researcher in psychology, and a secretary. Standardization was assessed after a pilot sample of patients was interviewed.

Semi-structured interviews were also carried out in small samples of patients from the 3 waiting lists, proportional to the sizes of the lists, and the trainees in psychology were trained for this task.

Prior to the interview, the patient or a relative was informed about the objectives of the research and about the freedom to agree or refuse to take part in the study. Most of the interviews to fill out the questionnaire were performed by telephone.

When no telephone was available, or its number was not right, the patients were sent letters asking them to call the interviewers or to go personally to the hospital to be interviewed. If neither the patients nor their relatives called or went to the hospital, a second letter was sent to them. Only the lack of response after a third letter was considered a refusal to take part in the study. The interviews were performed from July 1999 to May 2000.

For continuous quantitative variables, we calculated means and standard deviations and, for comparison of the means, we used the Student's $t$ test. For qualitative and categorical variables, we calculated the proportions and performed the chi-square test. We calculated survival tables using the Kaplan-Meier method for the events death and surgery, and the log rank test was used to compare the curves.

Death was considered an end point only when occurring before surgery. In the cases in which death occurred during or after the procedure, surgery was considered the end point. In all tests, the significance level adopted was $\alpha=0.05$. The statistical analysis was performed with the 6.0 version of the SPSS software for Windows ${ }^{10}$.

\section{Results}

A large number of letters were returned because the address was wrong, the patient had moved, the addressee was unknown, or the location was inaccessible. Some telephone numbers found in the medical records were not correct. Therefore, we were not able to contact several patients who were on the waiting lists. We interviewed a total of 705 patients or their relatives who were on the 3 waiting lists.

The waiting list for patients with coronary heart disease from $1 / 13 / 93$ to $12 / 31 / 98$ comprised 1,102 patients. We managed to interview 484 patients or their relatives, corresponding to only $44 \%$ of the total of the list.

The waiting list for patients with valvular heart diseases from 5/22/92 to $12 / 31 / 98$ comprised 163 patients. We managed to contact 121 patients or their relatives, accounting for $74.2 \%$ of the total of this list.

The waiting list for patients with congenital heart diseases from $3 / 8 / 94$ to $12 / 31 / 98$ comprised 226 patients. We managed to interview 100 patients or their relatives, corresponding to $44.3 \%$ of the total of this list.

The patients with coronary heart disease interviewed consisted of 143 females, whose ages ranged from 27 to 84 years (mean of $61.1 \pm 9.8$ and median of 61 years) and $341 \mathrm{ma}-$ les, whose ages ranged from 34 to 84 years (mean of $60.4 \pm 9$ and median of 62 years). The difference between the means was not statistically significant. In regard to the places the patients came from, $86.4 \%$ came from greater São Paulo city, $8.3 \%$ from inner São Paulo state, and 5.3\% from municipalities of other states.

In regard to occupational activity, 249 (73\%) males were inactive and only $92(27 \%)$ were active. In regard to the females, $108(75.5 \%)$ were housewives, $24(16.8 \%)$ were retired, and only $11(7.7 \%)$ had a professional activity.

The waiting time ranged from 3 days to 77 months (mean of $23.8 \pm 21.4$ months, median of 19 months). For the female patients, the waiting time ranged from 7 days to 75 months (mean of $23.3 \pm 21$ months, median of 18 months). For the male patients, the waiting time ranged from 3 days to 77 months (mean of $24.1 \pm 21.6$ months, median of 19 months). The difference between the means was not statistically significant.

Mortality of the patients with coronary heart disease during the waiting time was $11.2 \%, 19(13.3 \%)$ deaths among females and $35(10.3 \%)$ deaths among males. The difference between mortality for both sexes was not statistically significant. To better compare mortality in regard to the different waiting times, patients/year coefficients were calculated. Therefore, mortality for all patients during the waiting period was 5.6 deaths per 100 patients/year, 6.8 deaths per 100 patients/year for females and 5.1 deaths per 100 patients/year for males.

Figure 1 shows the survival curves of the patients with coronary heart disease on the waiting list according to sex. Analyzing the graph, we see a progressive reduction in the accumulated probability of survival for both sexes, with a more marked reduction for females after 48 months of waiting. However, the log rank test for comparison of the 2 curves was not statistically significant. We can also observe in this graph that the accumulated survival up to 60 months was around $80 \%$ for males and slightly below $60 \%$ for females.

In regard to surgery performance, $87(60.8 \%)$ females and $183(53.7 \%)$ males underwent surgery. The difference between the sexes was not statistically significant.

Figure 2 depicts the curves of accumulated probability of the patients with coronary heart disease not undergoing surgery during the waiting period according to sex. In the graph, we can see that with a 24-month waiting time, approximately half of the males and $45 \%$ of the females still had 


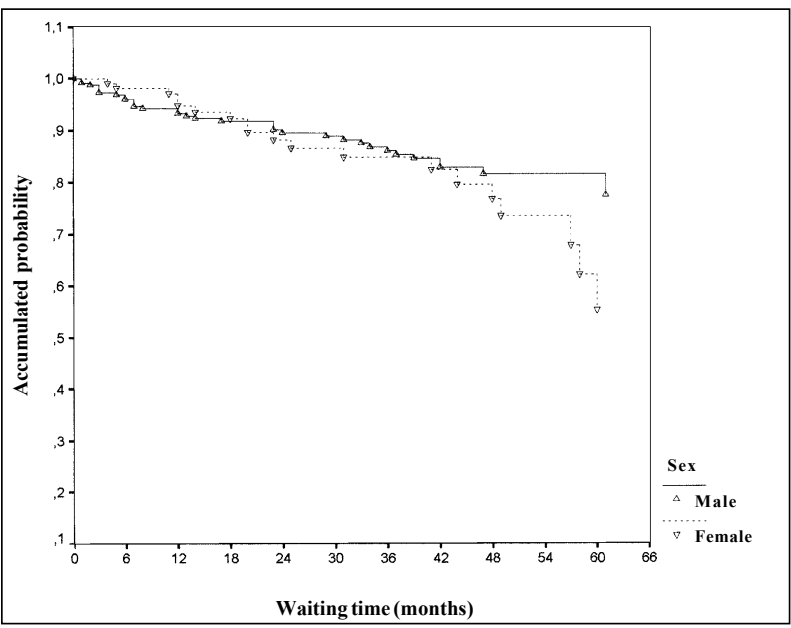

Fig. 1 - Survival of the patients with coronary heart disease on the waiting list for surgery according to sex.

not undergone surgery. The difference between both curves was not statistically significant.

The patients with valvular heart diseases interviewed were 69 females aged from 15 to 75 years (mean of $52.0 \pm 15.13$, and median of 55.0) and 52 males aged from 15 to 77 years (mean of 54.9 \pm 17.05 , and median of 61.0). The difference between the means was not statistically significant.

In regard to the site of the most frequent lesions, 54 (44.6\%) were in the mitral valve, $31(25.6 \%)$ in the aortic valve, and 25 (20.7\%) in both valves, isolated or associated with other diseases; 11 (9.1\%) patients were candidates for surgical replacement of the valvular prostheses.

In regard to the place of origin, $74.4 \%$ of the patients came from greater São Paulo city, $12.4 \%$ from inner São Paulo state, and $13.3 \%$ from municipalities of other states.

In regard to occupational activity, 28 (53.4\%) males were active and 24 (46.2\%) males were inactive; $48(69.6 \%)$ females were housewives, 11 (15.9\%) were retired, and 10 $(14.5 \%)$ were professionally active.

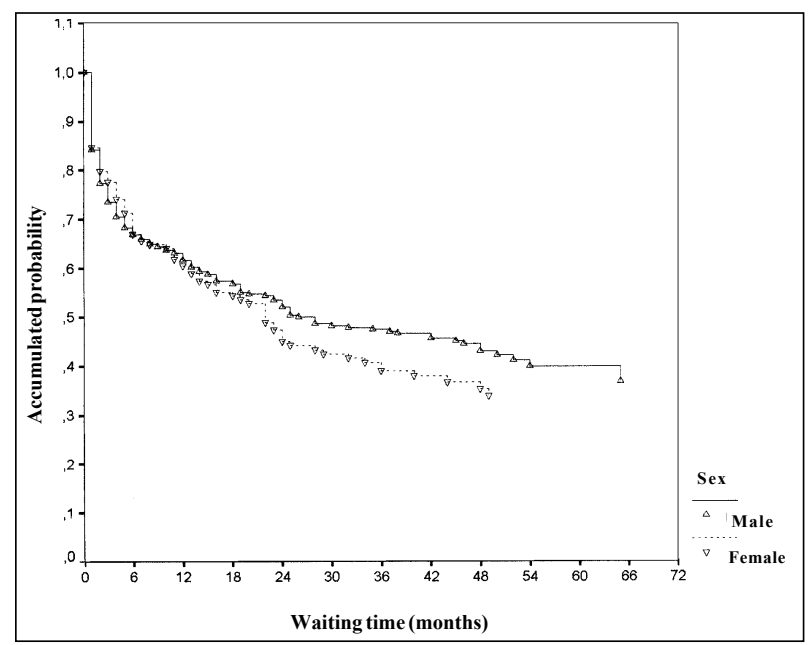

Fig. 2 - Accumulated probability of not undergoing surgery for the patients with coronary heart disease on the waiting list for surgery according to sex.
The mean waiting time was $27.8 \pm 22.7$ months (median of 25 , ranging from 6 days to 96 months). For the female sex, the mean waiting time was $32.9 \pm 24.8$ months (median of 26 months, ranging from 1 to 96 months). For the male sex, the mean waiting time was $21.1 \pm 17.8$ months (median of 17.5 months, ranging from 6 days to 68 months). The difference between the means was statistically significant $(\mathrm{p}<0.01)$.

The mortality rate was $29.8 \%$, with 21 deaths $(30.4 \%)$ among females and 15 deaths (28.8\%) among males; the difference, however, was not statistically significant. Mortality for both sexes related to the waiting times was 12.8 deaths per 100 patients/year, with 11.1 deaths per 100 patients/year in the female sex and 16.4 deaths per 100 patients/year in the male sex.

Figure 3 depicts the survival curves according to sex of the patients with valvular heart diseases who were on the waiting list. Analyzing the graph, we observe a gradual reduction in the accumulated probability of survival, which reaches approximately $60 \%$ between 36 and 60 months of waiting for males and approximately $55 \%$ between 48 and 84 months of waiting for females. The difference between both curves was not statistically significant.

In regard to surgery performance, $15(21.7 \%)$ females and $19(36.5 \%)$ males underwent surgery; the difference, however, was not statistically significant.

Figure 4 depicts the curves of accumulated probability of the patients with valvular heart diseases not undergoing surgery during the waiting time according to sex. Analyzing the graph, we see that the probability of not undergoing surgery was greater among females than among males, and the difference between the curves was statistically signifi$\operatorname{cant}(\mathrm{p}<0.01)$.

We interviewed 100 patients with congenital heart diseases, 70 of whom were females with ages ranging from 1 month to 62 years (mean of $17.5 \pm 18.1$ and median of 9.5 years); 30 were males with ages ranging from 1 month to 56 years (mean of $6.3 \pm 10.7$ and median of 2.0 years). The difference between the means was statistically significant $(p<0.01)$.

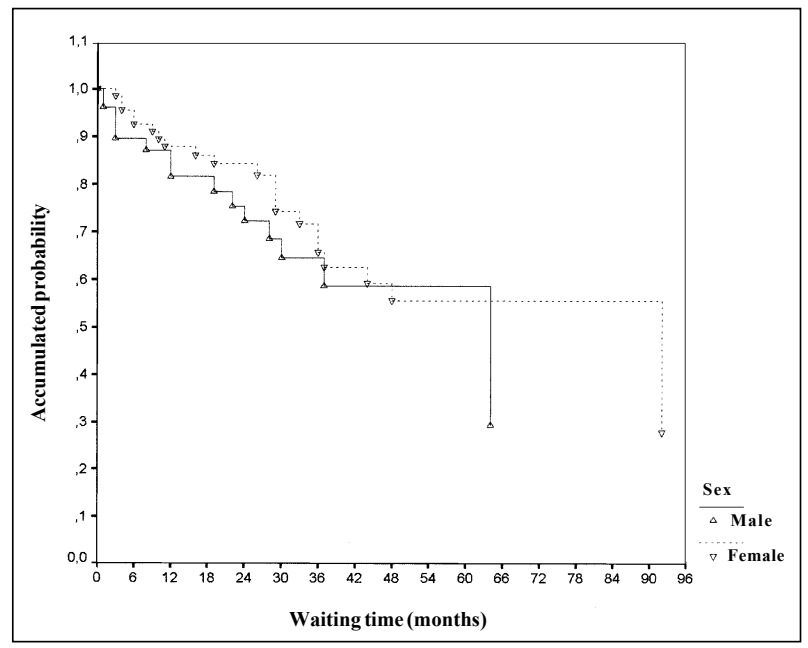

Fig. 3 - Survival of the patients with valvular heart disease on the waiting list for surgery according to sex. 


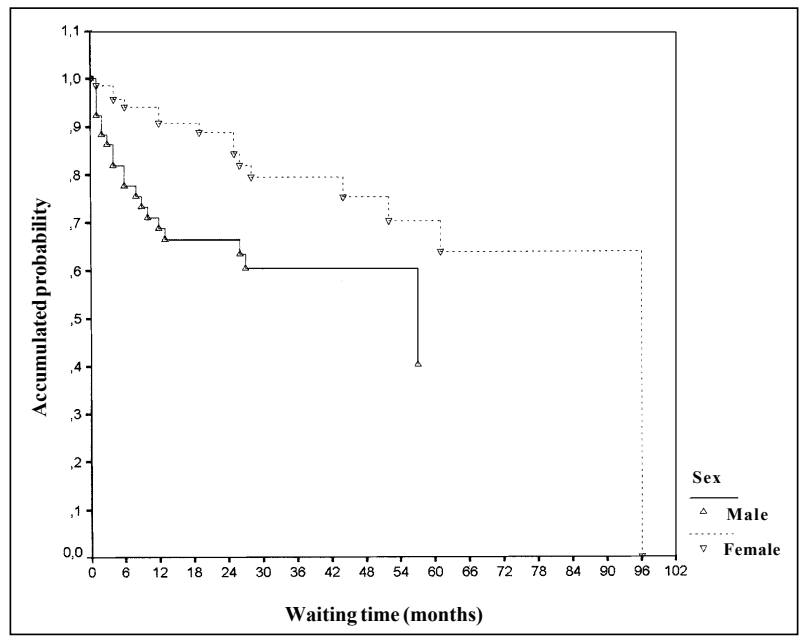

Fig. 4 - Accumulated probability of not undergoing surgery for the patients with valvular heart disease on the waiting list for surgery according to sex.

In regard to the most prevalent congenital abnormalities, $45 \%$ of the patients had atrial septal defect, $30 \%$ ventricular septal defect, and $9 \%$ persistence of ductus arteriosus, in isolated forms or associated with other types of lesions.

In regard to the place of origin, $46 \%$ of the patients came from greater São Paulo city, $36 \%$ came from inner São Paulo state, and $18 \%$ from municipalities of other states.

In regard to occupational activities, 65 patients were under the age of 18 years; of the 35 adults, $22(62.9 \%)$ were active, 2(5.7\%) inactive, and 11 (31.4\%) were housewives.

The mean waiting time was $15 \pm 11.8$ months (median of 13 months, ranging from 6 days to 70 months). For the female sex, the mean waiting time was $14.8 \pm 11.4$ months (median of 12 months, ranging from 6 days to 70 months). For the male sex, the mean waiting time was $15.5 \pm 13$ months (median of 13.5 months, ranging from 1 to 66 months). The difference between the means was not statistically significant.

The mortality of the patients with congenital heart disease during the waiting time was $4 \%$, with $3(4.3 \%$ ) deaths among females and $1(3.3 \%)$ death among males; the difference, however, was not statistically significant. The mortality of the patients with congenital heart diseases in regard to the waiting time was 3.1 deaths per 100 patients/year, with 3.5 deaths per 100 patients/year in the female sex and 2.6 deaths per 100 patients/year in the male sex.

Figure 5 depicts the curves of accumulated probability of survival of the patients with congenital heart disease on the waiting list according to sex. Analyzing the graph, we can see that survival was high for both sexes, with no statistically significant difference.

In regard to surgery performance, $32(45.7 \%)$ females and $16(53.3 \%)$ males underwent surgery; this difference, however, was not statistically significant.

Figure 6 depicts the curves of accumulated probability of the patients with congenital heart disease not undergoing surgery during the waiting time according to sex. We observe that this probability is slightly higher for females, but the difference between the curves was not statistically significant.

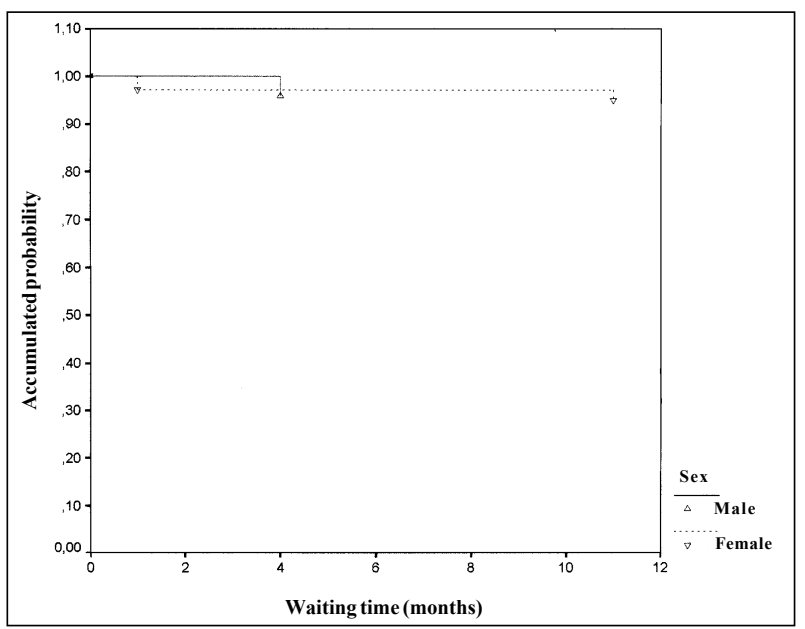

Fig. 5 - Survival of the patients with congenital heart disease on the waiting list for surgery according to sex.

Comparing mortality in the 3 waiting lists, we observe that mortality was higher among patients with valvular heart diseases $(29.8 \%)$ than among those with coronary heart disease $(11.2 \%)$ and those with congenital heart disease (4\%). The difference was statistically significant $(\mathrm{p}<0.0001)$.

Figure 7 depicts the curves of accumulated probability of survival corresponding to the 3 waiting lists. Analyzing the graph, we observe that the patients with valvular heart diseases had lower survival levels during the waiting time than the patients with coronary heart disease and the patients with congenital heart diseases. The difference between the 3 curves was statistically significant $(p<0.001)$.

Figure 8 depicts the accumulated probabilities of the patients on the 3 waiting lists not undergoing their respective surgeries. Analyzing the graph, we observe that these probabilities are higher in the patients with valvular heart diseases than in those with coronary heart diseases or with congenital heart diseases. The difference between the 3 curves was statistically significant $(p<0.001)$.

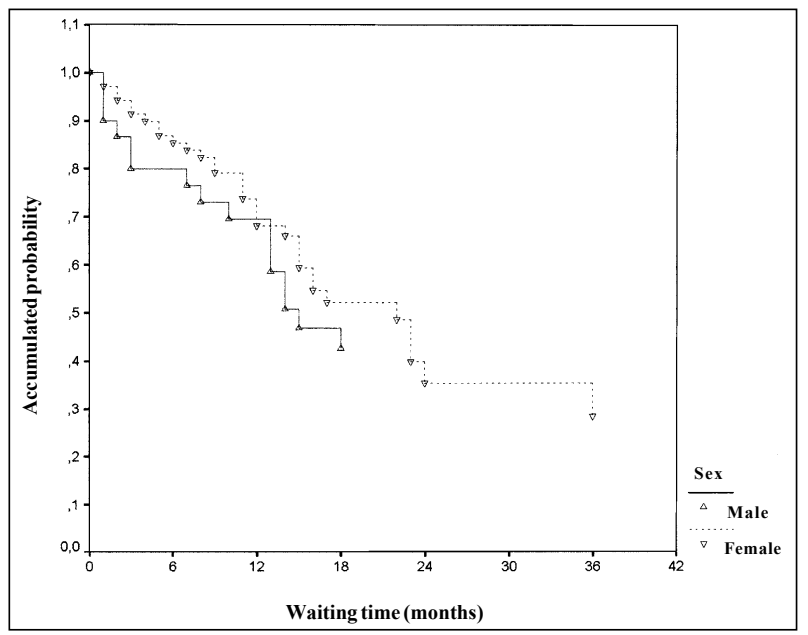

Fig. 6 - Accumulated probability of not undergoing surgery for the patients with congenital heart disease on the waiting list for surgery according to sex. 


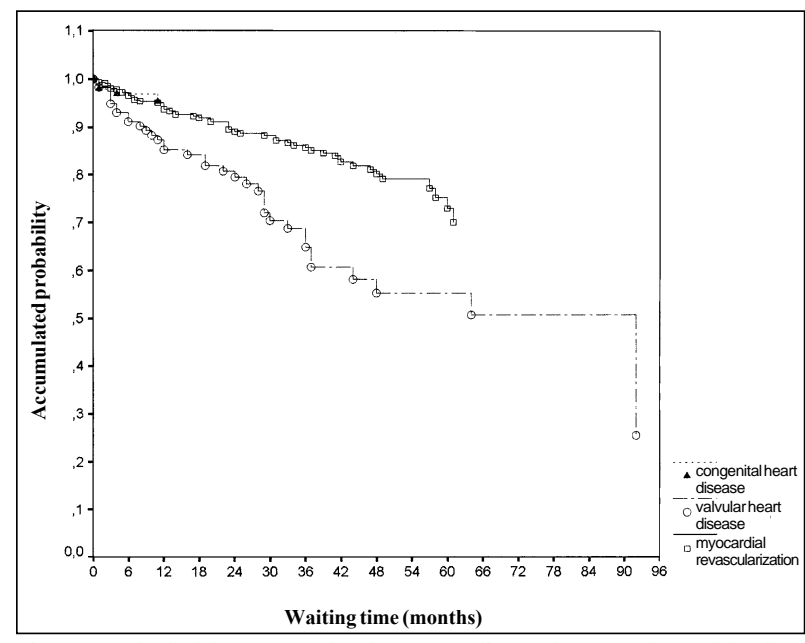

Fig. 7 - Survival of the 3 types of patients according to the respective waiting lists for surgery.

The analysis of the material obtained in the psychological interviews made possible the identification of 4 groups of patients. Each group was classified according to the specificity of the attitudes, feelings, and emotional reactions in regard to the time awaiting surgical treatment for heart disease. In the $1^{\text {st }}$ group, the patients considered themselves within the waiting time for surgery. In the $2^{\text {nd }}$ group, the patients complained that the waiting list was an obstacle to their survival and were extremely anxious, because they could see the progressive deterioration of their organic condition. The adaptive problems in their love, professional, and social lives were attributed to not undergoing surgical treatment for their heart disease. The patients in the $3^{\text {rd }}$ group denied the need for surgery. For some of them, the time spent on the waiting list proved that surgery was not really necessary, confirming their refusal for surgical treatment. For others, the long waiting time had weakened the initial motivation at the time of surgery indication, and now they did not feel the need for undergoing surgery. In the $4^{\text {th }}$

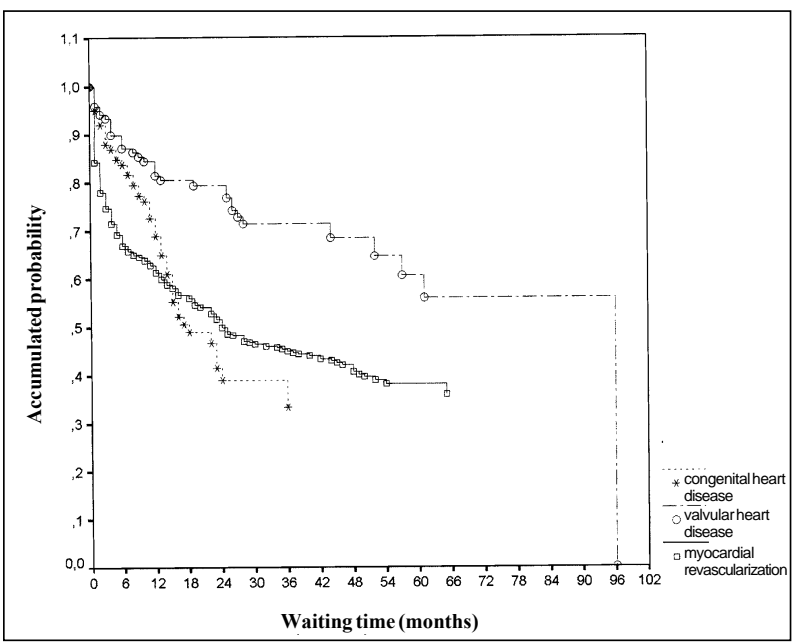

Fig. 8 - Accumulated probability of not undergoing surgery for the 3 types of patients according to the respective waiting lists for surgery. group, the waiting time favored the patients, who put the problem of surgery on hold while remaining involved in solving psychological difficulties like depression, which were not associated with the presence of heart disease.

No statistically significant differences were found between the groups in regard to the difficulties about the topics discussed during the psychological interview, such as previous problems of compliance to medical treatment, antecedents of alcohol abuse, specific knowledge about the heart disease and the surgical treatment, familial support, and complaints about the physicians or hospital.

The mean waiting time in the $2^{\text {nd }}$ group was the shortest $(17$ months $)$, while the mean waiting time in the $3^{\text {rd }}$ group was the longest (33 months).

The results of this study showed that, in the initial phase, indication for surgery triggered a psychological crisis, for which the patient sought an adaptive solution focussing all of his/her attention on solving the problem. However, prolonging the waiting time for elective surgery caused a reduction in the patient's motivation to undergo the treatment, and even eliminated the need for that procedure from some patients' points of view.

\section{Discussion}

Due to the already cited problems, for example unavailability of addresses and telephone numbers of several patients, this study had limitations because the survey did not achieve ideal proportions of responses as follows: only a $44 \%$ response from patients with coronary heart disease, $74.2 \%$ from patients with valvular heart diseases, and $44.3 \%$ from patients with congenital heart disease. However, we believe no selection bias occurred in the choice of patients and their relatives to take part in the study.

The total number of patients operated upon at our institution for myocardial revascularization surgery and repair of valvular heart diseases and of congenital heart diseases is higher than that in our study. This is due to the fact that a large number of the surgeries were performed immediately after their indications, due to the severity of the cases, with no waiting time. We estimate that these patients represent approximately $20 \%$ to $30 \%$ of all patients operated upon.

The median waiting time of the patients with coronary heart disease was very prolonged (18 months for females and 19 months for males) as compared with that in developed countries as follows: a median of 17 days in the State of New York, 72 days in the Netherlands, 59 days in Sweden ${ }^{6}$, 5 to 6 months in Iceland ${ }^{7}$, and 181 days in 1993 and 212 days in 1995 in New Zealand ${ }^{5,9}$. The mean waiting time in Toronto, Canada, between 1989 and 1991 was 35 days ${ }^{1}$.

The Health Council of the Netherlands in $1995{ }^{11}$ recommended that the maximum waiting time for myocardial revascularization surgery should be 2 to 3 months.

Langham et al ${ }^{12}$ reviewed the medical records of 1,594 patients undergoing myocardial revascularization surgery in 1992 and 1993 in 3 hospitals in London. Comparing the waiting times of these patients with those recommended by 
an adapted version of the urgency score system in Canada, these authors observed that $28 \%$ of the patients underwent surgery after the maximum waiting time established.

In our study, the mortality of the patients with coronary heart disease during the waiting time was high (11.2\%) with a death coefficient of 5.6 per 100 patients/year. In the Netherlands, in $1986^{13}$, this coefficient was 8.3 deaths per 100 patients/year.

In a retrospective study carried out in Germany, Preusse et $\mathrm{al}^{14}$ reported a $2.3 \%$ mortality rate for patients with coronary heart disease on the waiting list for heart surgery from 1988 to 1992, and, for patients with aortic valve disease, the mortality rate was even higher, reaching $4.3 \%$.

Morgan et al ${ }^{8}$, studying 29,293 consecutive patients of 9 heart surgery units in the province of Ontario, Canada, from October 1991 to June 1995 , found a $0.48 \%$ mortality rate. Adjusting for age, sex, and waiting time, the patients waiting for valvular heart surgery had a higher risk of mortality than those with coronary heart disease (odds ratio $=1.88$, $95 \%$ confidence interval $=1.23-2.88$ ).

In Denmark, Lund et al ${ }^{15}$, in a prospective study of 99 patients with severe aortic stenosis, reported that the waiting time for surgery ranged from 0.5 to 19 months, with a mean of 6.3 months. The mortality coefficient during the waiting time was 13.5 deaths per 100 patients/year, and, after valvular surgery in a mean follow-up of 5.7 years, the mortality coefficient was 4.9 deaths per 100 patients/year.

In our study, the mortality rate was also higher among the patients with valvular heart disease than among those with coronary heart disease or with congenital heart disease (29.8\%, $11.3 \%$, and 4\%, respectively); survival, therefore, was shorter in the former patients. The low mortality rate observed in patients with congenital heart disease may be due to the fact that the more complex and severe cases in children are immediately referred for surgery, without placement on the waiting list. Most patients on the waiting list had atrial septal defect (45\%), ventricular septal defect $(30 \%)$, or persistence of ductus arteriosus $(9 \%)$ isolated or associated with other congenital defects.

When comparing the sexes of patients with coronary heart disease, the accumulated survival up to 60 months was approximately $80 \%$ for males and $60 \%$ for females, but this difference was not statistically significant. In the patients with valvular heart diseases and in those with congenital heart disease, the comparison of the survival curves between the sexes was not also statistically different. However, when analyzing the curves of the accumulated probability of not undergoing surgery for the patients with valvular heart diseases according to sex, the female sex had the higher curve and the difference was statistically significant. These female patients, younger than those with coronary heart disease, usually postponed their surgeries due to domestic problems, such as child rearing, when invited to undergo surgery.

Naylor and Levinton ${ }^{16}$, in a prospective study with 131 females and 440 males carried out in Toronto, Canada, reported that the physicians indicated more myocardial revascularization surgery for the male patients with coronary heart disease than for the female patients, and, once the patients accepted the indication for surgery, more males than females underwent the procedure.

In regard to the psychological consequences of prolonging the waiting time, Jonsdottir and Baldursdottir ${ }^{7}$ carried out a study in Iceland mailing questionnaires to patients with coronary heart disease with a mean waiting time for surgery of 5 to 6 months. These authors observed that several negative effects existed on the work and daily life of most patients and that they were not satisfied with their health status, due to major symptoms, such as fatigue, dyspnea, chest pain, anxiety, and depression, which had negative repercussions on their families.

Teo et al ${ }^{17}$, in Canada, carried out a survey with telephone interviews, in which a standardized questionnaire was applied to 102 patients with coronary heart disease who had been on the waiting list for surgery for more than 6 weeks, to assess the quality of life perceived by these patients. Approximately $87 \%$ of the patients reported that their quality of life had worsened since they had been placed on the waiting list, mainly in regard to issues related to work, income, stress, social support, and frustration.

In our study, data obtained showed that at the time surgery was indicated, a psychological crisis was triggered, to which the patient sought an adaptive solution. With the prolonged waiting time, several patients complained that the list was an obstacle to their survival, that their organic conditions were in progressive deterioration, were extremely anxious, and had adaptive problems in regard to their love, professional, and social lives. On the other hand, other patients considered that time had weakened the initial motivation existing at the time surgery was indicated, and they no longer considered the surgery necessary.

Excessive prolongation of the waiting time had several consequences, such as increased mortality, which was higher among patients with valvular heart diseases, and the psychological and social problems highlighted in the study.

Greater investments in material and human resources should be implemented so that the saving ability of surgical treatment can meet the increasing demand of patient candidates for heart surgery.

In the long run, to reduce this demand, primary and secondary prevention should be emphasized to better control risk factors and to provide early diagnosis and treatment of heart diseases. 


\section{References}

1. Naylor CD, Morgan CD, Levinton CM, et al. Waiting for coronary revascularization in Toronto: 2 years' experience with a regional referral office. Can Med Assoc J 1993; 149: 955-62

2. Carrier M, Pineault R, Tremblay N, Pelletier LC. Outcome of rationing access to open-heart surgery: effect of the wait for elective surgery on the patient outcome. Can Med Assoc J 1993; 149: 1117-22.

3. Naylor CD, Sykora K, Jaglal SB, Jefferson S, and The Steering Committee of the Adult Cardiac Care Network of Ontario. Waiting for coronary artery bypass surgery: population-based study of 8,517 consecutive patients in Ontario, Canada. Lancet 1995; 346: 1605-9.

4. Cox JL, Petrie JF, Pollak PT, Johnstone DE. Managed delay for coronary artery bypass graft surgery: the experience at one Canadian center. J Am Coll Cardiol 1996; 27: 1365-73.

5. Doogue M, Brett C, Elliot JM. Life and death on the waiting list for coronary bypass surgery. N Z Med J 1997; 110: 26-30.

6. Berstein $\mathrm{SJ}$, Rigter $\mathrm{H}$, Brorsson $\mathrm{B}$, et al. Waiting for coronary revascularization: a comparison between New York State, The Netherlands and Sweden. Health Policy 1997; 42: 15-27.

7. Jonsdottir H, Baldursdottir L. The experience of people awaiting coronary artery bypass graft surgery: the Icelandic experience. J Adv Nurs 1998; 27: 68-74.

8. Morgan CD, Sykora K, Naylor CD. Analysis of deaths while waiting for cardiac surgery among 29,293 consecutive patients in Ontario, Canada. The Steering Committee of the Cardiac Care Network of Ontario. Heart 1998; 79: 345-9.
9. Jackson NW, Doogue MP, Elliot JM. Priority points and cardiac events while waiting for coronary bypass surgery. Heart 1999; 81: 367-73.

10. SPSS for Windows Release 6.0. Chicago, SPSS Inc., 1993.

11. Lie KI. Heart surgery and interventional cardiology for adults; Health Council recommendations. Ned Tijdschr Geneeskd 1995; 139: 1220-2.

12. Langham S, Soljak M, Keogh B, Gill M, Thorogood M, Normand C. The cardiac waiting game: are patients prioritized on the basis of clinical need? Health Serv Manage Res 1997; 10: 216-24.

13. Suttorp MJ, Kingma JH, Koomen EM, Tijssen JG, Defauw JA, Ernst JM. Predictive characteristics for early mortality in patients on the waiting list for aortocoronary bypass surgery. Ned Tijdschr Geneeskd 1989; 133: 2441-5.

14. Preusse CJ, Angenendt S, Schulte HD. Preoperative mortality of heart surgery patients. Z Kardiol 1998; 87(Suppl 2): 116-24.

15. Lund O, Nielsen TT, Emmertsen K, et al. Mortality and worsening of prognostic profile during waiting time for valve replacement in aortic stenosis. Thorac Cardiovasc Surg 1996; 44: 289-95.

16. Naylor CD, Levinton CM. Sex-related differences in coronary revascularization practices: the perspective from a Canadian queue management project. Can Med Assoc J 1993; 149: 965-73.

17. Teo KK, Spoor M, Pressey T, et al. Impact of managed waiting for coronary artery bypass graft surgery on patients' perceived quality of life. Circulation 1998; 98(Suppl): II 29-33.

\section{"Informações Resumidas do Produto"}

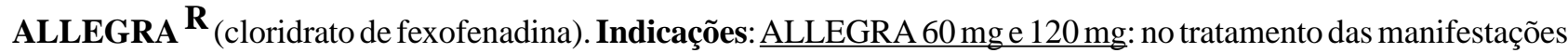
alérgicas, tais como a rinite alérgica. ALLEGRA $180 \mathrm{mg}$ : no tratamento das manifestações alérgicas da urticária. Contra-indicações: em pacientes com antecedentes de hipersensibilidade a qualquer componente da fórmula. Gravidez e Lactação : não deve ser usado durante a gravidez e lactação a menos que a relação risco/benefício seja avaliada pelo médico e supere os possíveis riscos para o feto. Interações medicamentosas: a administração concomitante de cloridato de fexofenadina com eritromicina ou cetoconazol não demonstrou nenhum aumento significativo no intervalo QTc. Não foi relatada nenhuma diferença nos efeitos adversos no caso destes agentes terem sido administrados isoladamente ou em combinação. A administração de de um antiácido contendo hidróxido de alumínio e magnésio, aproximadamente 15 minutos antes da fexofenadina, causou redução na biodisponibilidade. Recomenda-se aguardar um período aproximado de 2 horas entre as administrações de fexofenadina e antiácidos que contenham hidróxido de alumínio e magnésio.ReaçõesAdversas: nos estudos placebo-controlados em criaças com 6 a 11 anos de idade, os eventos adversos foram similares àqueles nos estudos clínicos envolvendo adultos e crianças de 12 anos ou mais. A incidência foi similar à observada com o uso de placebo; os eventos adversos mais freqüentes relatados em adultos incluem: cefaléia, sonolência, vertigem e náuseas. Outras reações mais raras e que foram relatadas em adultos incluem : fadiga, insônia, nervosismo, alterações do sono ou pesadelos, eritema cutâneo, urticária, prurido e reações de hipersensiblidade tais como angioedema, dispnéia, rigidez toráxica, rubor e anafilaxia sistêmica. Posologia: Rinite Alérgica: para adultos e crianças acima de 12 anos, recomenda-se 1 cápsula de $60 \mathrm{mg}, 2$ vezes ao dia ou 1 comprimido de $120 \mathrm{mg}, 1$ vez ao dia. Urticária: para adultos e crianças acima de 12 anos, recomenda-se 1 comprimido de $180 \mathrm{mg}, 1$ vez ao dia. Para rinite alérgica, a eficácia e a segurança em crianças abaixo de 6 anos de idade ainda não está estudada. Para urticária, a eficácia e a segurança em crianças abaixo de 12 anos de idade ainda não está estudada. Não é necessário ajuste de doses em pacientes idosos ou com insuficiência hepática, renal ou idosos. Composição e Apresentações: Cápsulas de $60 \mathrm{mg}$ (caixas com 10): cada cápsula contém o equivalente a $56 \mathrm{mg}$ de fexofenadina; Comprimidos de $120 \mathrm{mg}$ (caixas com 10): cada comprimido contém o equivalente a $112 \mathrm{mg}$ de fexofenadina; Comprimidos de $180 \mathrm{mg}$ (caixas com 10): cada comprimido contém o equivalente a $168 \mathrm{mg}$ de fexofenadina.

VENDA SOB PRESCRIÇÃO MÉDICA. Registro MS 1.1300.0258. Data de Revisão: 26/12/00. "Para maiores informações antes de sua prescrição, favor ler bula completa do produto" 